\title{
Are networks important in order to secure a firm's strategy? - A literature review
}

Miguel Córdova

Pontificia Universidad Católica del Perú

cordova.miguel@pucp.edu.pe

Desde las investigaciones de Granovetter (1973) acerca de los lazos débiles y fuertes en una red de relaciones, se ha escrito numerosa literatura sobre el potencial de las redes para obtener más recursos, reducir la incertidumbre del entorno $y$, finalmente, asegurar las estrategias en las firmas. En este artículo presentamos la estrategia de una empresa como una plataforma desde donde construir con variadas herramientas y recursos clave, y también como una plataforma de desarrollo en tiempo real, ya que está constantemente influenciada por las redes. Las redes tienen poder y sus beneficios son el resultado de una adecuada comprensión del tema por parte de las empresas. Por ejemplo, la propia capacidad para aprender de ellas y saber movilizarlas cuando es necesario. Las redes no solo influyen en la cantidad y calidad de los recursos que una empresa pueda obtener, también son capaces de influir en el entorno a fin de facilitar la movilización de estos recursos en el momento adecuado.

Palabras clave: redes, estrategia, capital social, recursos, vínculos sociales

Since Granovetter's (1973) research on weak and strong ties in relationship networks, a great amount of literature has been written about the network's potential for firms in order to obtain more and different resources, reduce uncertainty from the environment, and finally secure its strategy. In this paper I present the strategy as a platform to build on with several key tools and resources, also as a real time development platform since it's constantly influenced by networks. Networks are powerful indeed, and firms benefit from understanding its potential and capability to learn from it and mobilize it when it's necessary. Networks not only influence the quantity and quality of resources that a firm can obtain, but, are also proficient in affecting the environment as well in order to facilitate the mobilization of these resources in the proper time.

Keywords: networks, strategy, social capital, resources, social ties 


\section{Introduction}

The main purpose of this paper is to do a literature review about networks and strategies, in order to discover their similarities and understand how networks can help to secure a firm's strategy. I will present the literature reviewed in two main parts. First, by establishing the relation between both concepts and then by closing with some general ideas and some answers to these research questions:

1. Which are the most valuable resources commonly obtained by firms using networks?

2. What conditions are involved in the decisions of organizations when choosing network strategies?

The conclusions of this review can guide us in finding new paths to explore the relationship between these two concepts and the importance of their different applications in many organizational fields or industries.

\section{What is there between networks and strategies?}

\subsection{Networks under a new perspective: Social capital}

\subsubsection{Networks and ties}

As far as we can approach to the concept of a network, we could think about it as a group of people with several connections to each other. In a social point of view, these connections could help us identify the reasons for people's behavior (Mitchell, 1969; on Mitchell, 1974). But, we can see them also as a group of firms or organizations, linked by many relationships between them and sharing multiple connections, forming different networks structures (Tichy, Tushman \& Fombrun, 1979). Furthermore, when the networks analysis began and took as a new concept with apparently many implications in the organizations behavior and performance, we face the necessity to begin to study every one of its elements in order to gain a better understanding about to whole network system.

Therefore, it was found that in every network system there're not just people or organizations who connect to each other, but there're links also, called ties (Granovetter, 1973) with many different characteristics and particularities. These ties can be of two different types: weak and strong. Strong ties are connections between two persons or organizations that are very close to each other. This means, that the tie reflects a certain degree of intimacy and a near relationship. On the other hand, weak ties are connections that aren't close or personal. They represent individuals that we keep in touch or visit as an eventual manner. According to Granovetter's (1973) research, the ties formed between two different actors may enhance the generation of multiple resources. The strong ties may enable resources as confidence, trust and support. Meanwhile, weak ties enable external and new resources that the person or the organization did not have idea of their existence before. According to this, weak ties could represent a new external basis of different and 
valuable resources for the organization, mainly information (1973). With this idea in mind, we can conceive weak ties in a network as more powerful and important than strong ties, when an organization wants to develop its strategy and maintain a competitive advantage over time through its resources.

\subsubsection{Bridges and structural holes in a network}

Inside a network there are more elements than weak or strong ties. There are also empty spaces between the actors. These empty spaces represent no existence of link or connection, and could generate the construction of bridges to try to establish connections in order to have access to resources that are in the other side (Granovetter, 1973). These empty spaces or possible bridges also receive the name of structural holes. They represent a flow of information that is not redundant to the network (Burt, 1992). With non-redundant information, organizations have access to a lot of different resources. This means the presence of empty spaces are important and necessary. Burt mentioned this by giving importance to the fact that an actor can maintain in time these structural holes, serving itself with the non-redundant information benefits.

The analysis of networks implies the review of how many weak ties are present, in order to secure the amount of information or another important resources. But it also has to review the number of structural holes in order to have the opportunity of obtaining new and different information every time through the same connections.

Burt (2004), in a more recent research, established the relationship between the presence of structural holes in networks and the capacity of a firm to innovate and generate new good ideas to develop. This relationship could be very important to a firm whose purpose is to secure and maintain its strategy over time through innovation and differentiation.

\subsubsection{Developing Network}

As it was mentioned in the resource dependence theory (Pfefer \& Salancik, 1978; in Martin, Gozubuyuk \& Becerra, 2013), firms in general search for valuable resources in order to confront uncertainty. But, this uncertainty could moderate in some cases the relationship between performance and presence of networks. This means that in situations of uncertainty, networks could mobilize their resources to enhance the firm's performance. However, this occurs only in cases where the environment uncertainty is strong. In other situations, for example, a directorate interlock, the presence of a network, can remain unnoticed to the firms' performance (Martin \& others, 2013).

Resources can also be found in partners with different or complementary skills. The value of forming a network between them would enhance the generation of synergies between the participants, and they would have access to different information and resources (Hitt, Ireland, Camp \& Sexton, 2001). From these four authors we can conclude that intangible resources are more important for the organization than tangible resources, in order to maintain a competitive advantage in the market. These intangible resources are: reputation, knowledge, learning capability and the capacity to transfer knowledge. All of these resources are most commonly used by organizations in their strategy, basically 
through their network building capabilities, to keep and build competitive advantages in the different industries that their work in.

According to Hillmann \& Aven (2011), the reputation of better performance is obtained by using small and homogeneous network components. This affirmation comes from the initial idea that emerging economies seek to cover their lack of formal and competent institutions by putting their trust on informal and unorganized institutions as well. This contextual behavior generates a new concept of reputation-based networks, which are mostly present in under-development countries. On the other hand, large firms and advanced economies also require some kind of far-reaching networks to help them discover new opportunities from innovative information and different resources.

Reputation has two principal facets. The first one refers to the possibility of learning about a partner's behavior record. This probably can be very useful information when a firm wants to reduce the uncertainty when forming a new relationship with a partner. Therefore, reputation can be an important resource when a firm needs to establish new relationships with others that interact with it in a similar context. Secondly, reputation is perceived as a type of trust. A firm can also reduce the uncertainty of relying on another firm and ask for help or deliver responsibilities with greater confidence based on trust (Hillmann \& Aven, 2011).

Some of the resources that may be obtained by constructing and using the networks can actually help to improve performance in new international ventures (Coviello, 2006). These businesses use relationships generated by natural network evolution to adequate their strategies to foreign markets by making the distinction between young international new ventures and old ones, and the different ways how these entrepreneurial actors can acquire the basis for their future growth and sustainability.

In addition to this, entrepreneurial methods used to find opportunities for international exchange when exploring foreign markets are commonly grounded on the tie-based opportunities that emerge from relations with others. These kind of resources are called tie-based exchanges (Ellis, 2011). But, tie-based exchanges can only be produced by a fluent and sustained network system that allows the firm to obtain different and better opportunities to achieve positive exchanges or establish trust and confidence with others in the same network through enforcement and repetition of partner relations in a less open network system.

Networks can also be helpful to business initiatives, particularly poor countries due to the environmental conditions that surround the creation of businesses. Networks solve issues such as lack of information and resources very well (Maas, Seferiadis, Bunders, \& Zweekhorst, 2014). This is another positive fact involving networks capacity to permit a correct deployment of strategy and also entrepreneurship as well.

Networks are the main supply of external resources for some companies who have limited access to internal resources, and their major support in order to maintain a competitive strategy in their field (Yao, Wen \& Ren, 2009). Another research mentioned that the characteristic of mobilization of networks was a principal issue in order to achieve strategic differentiation (Hung, 2002). There are some companies that found their competitive advantages through trust relations generated inside their corporate networks. This idea is a contradiction to the traditional thinking scheme about how a 
firm builds its strategy, because despite the context and the competition forces in the industry, according to Hung, a firm can model its strategy on the present resources available from its actual corporate network and the relations of the founder also. In this empirical study, Hung presents three different technological companies in Taiwan who established their strategies through their networks. These three firms, Acer, Mitac and Fic, were also in the middle of other three kinds of networks, as appear in figure 1. They mobilized their resources by making use of one or more types of connections to define their own strategy.

Figure 1: A firm connected with three kinds of different social networks

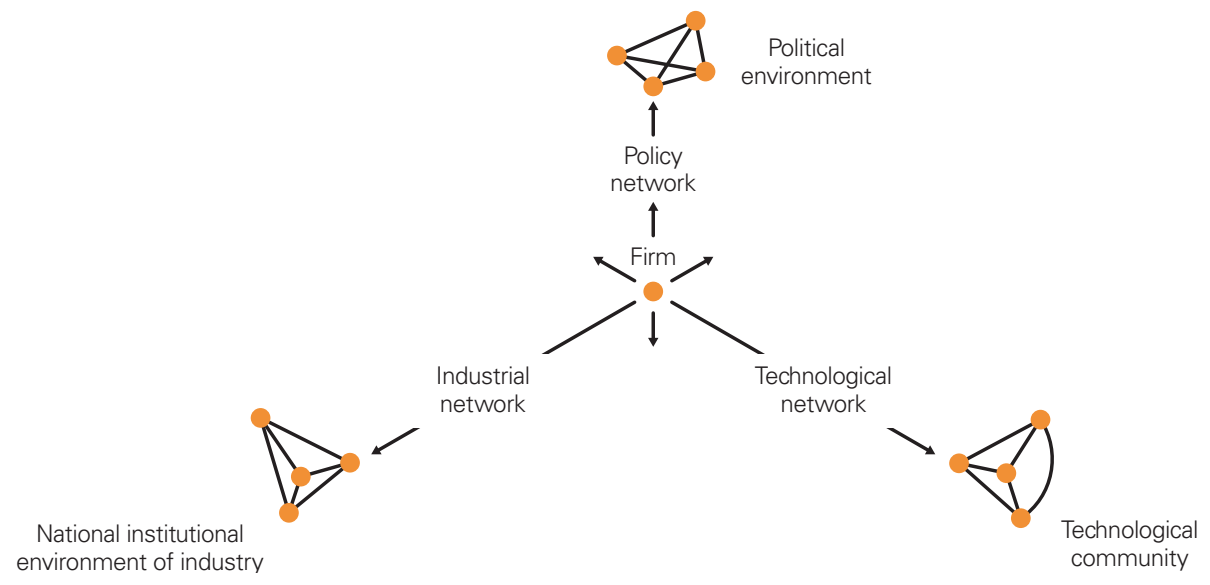

Fuente: Hung (2002).

As Coviello (2006) said in his research, international entrepreneurship or the attempt of any business to be successful in an international venture, must pay attention with extra care to the network theory and analysis, because it is very important to consider the network relations and ties (Granovetter, 1973) that are formed before the internationalization process, during the pre-internationalization phase. Also, he introduced a new point of view about this internationalization process, by arguing that from the perspective of the international entrepreneurship it's also very critical that the business can explain and manage its relations with other actors at a pre-founding phase. This means, that the ties that are formed before the very foundation of the business are important too (Hung, 2002), and also in the success of the later efforts to achieve the internationalization process.

International ventures also mean the identification and exploitation of several opportunities in international exchange between many actors connected in the same network (Ellis, 2011). This value and resource exchange can be performed in some particular contexts that basically are formed by networks, their different actors and participants. Any context with an inappropriate and/or not collaborative participant may interrupt or impede the natural flow of resources and information through the network. As a result of his study, Ellis concludes that one important way to enhance the many opportunities in an exploration of a foreign market is to build and sustain networks. Through networks, the entrepreneurial activity may achieve success in order to deliver a new source of supply for the buyer and a new open market to the seller. 
It is not always easy to begin a new company or an international venture. In some underdeveloped countries entrepreneurship is highly demanded by the populations wanting to leave poverty. However, there are limited resources and inefficient institutions that support entrepreneurial initiatives (Maas \& others, 2014). In this context of few opportunities to establish adequate entrepreneurial activities, there's an important task for networks and more specifically, for entrepreneurial networks, because these systems can provide the resources and the information that entrepreneurship need. Furthermore, in a study about technological entrepreneurship in China, it was discovered that the factors for an integrated framework to support technological entrepreneurship indeed existed, as well as external networks of the firm's opportunities and the power and relevance of local institutions (Petti \& Zhang, 2011). Networks then are also an important tool to ensure and provide an appropriate environment to establish this kind of business initiatives.

When any company or firm intends to do something new like creating a new division, enter into a new market or just expand its own product or service portfolio, it will need a variety of resources to do so. These kinds of initiatives are present in large, medium and small businesses and all of them want to achieve success in their own markets. Scholars have already done some research into how internal resources are available and influence the corporate entrepreneurship of the firms, but there are few studies about how external resources can influence on that type of entrepreneurship (Yao \& others, 2009). Moreover, the principal sources where those external resources are to be found are networks. The medium and small firms which have limited internal resources must seek external resources to complete their strategy. Therefore it's extremely important for medium and small size firms to build and sustain networks, much more so than for the large sized companies.

\subsubsection{Social capital as a result}

Social capital is defined as a group of resources obtained by building a network. It found its roots in the "goodwil» of people toward others, and to receive this "goodwill» means to have access to information, influence and solidarity (Adler \& Kwon, 2002). According to Adler \& Kwon, through these concepts, social capital provides different sources for new skills, knowledge, control, power and trust; all of which represent a group of strategic valuable resources from a network perspective. The concept of social capital was perhaps the beginning of a new idea about using networks in any organization.

But Adler \& Kwon also explained in their research that this "goodwill» has to achieve two actions in order to effectively deploy the concept. First, construct and maintain social relations; and second, the possibility to mobilize social capital in a particular context or situation in order to obtain specific results.

About twelve years later, in a new research about social capital, it was explained how this new concept had been evolving in the trends researched around the world and concluded that social capital had matured into a new whole organizational field. The study also mentioned the difference between having social capital and using social capital. This new approach means that if someone has access to some information, mobilization of the social capital occurs when someone is capable of using it. From this point of view, the 
new concept must be useful for the practitioners in the first place and scholars, because recent results of this new research highlight new paths for the study of social capital (Kwon \& Adler, 2014). Furthermore, according to Kwon \& Adler trust is capable of facilitating the movement of resources through the ties of a network, being high motivation the way to manage social capital in the firm.

\subsection{Strategy as a platform to build on}

\subsubsection{What is a strategy?}

Strategy is defined as a group of different conscious guidelines, with some relation to each other, usually a common idea that clears and establishes the organization's future decision (Mintzberg, 1978). Another more recent definition, mentions that a strategy always points to answer questions such as what and why in the organization. It can be a mistake if the strategy tries to answer the short-term questions of how or when (Phillips, 2011). Those definitions of strategy can help us present this concept as something very important for the future of the firm. All the decisions that a firm can make in the upcoming years have to consider organization's future performance, organization on the short-term actions and the long-term behavior.

\subsubsection{Strategy tripod for organizations}

The new organizational fields mentioned before must be understood from their very creation and as a result from a process. This process can be changed by the actors that participate in the field and by the institutions that also join in this same context. Previous research about how actors can change the process of creation in the organizational fields presents two theories. The first states that institutions are considered the third leg of a strategy tripod for the organizations (Peng, Li Sun, Pinkham \& Chen, 2009) along with the industry-based (Porter, 1980) and the resource-based views (Barney, 1991). This idea also includes the explanation of how formal and informal institutions that can change a firm's strategy. The second premise considers that not only can institutions deliver new models to organizational fields, but the actors as well play an important role in changing how institutions work in the context of a particular organizational field (Battilana, Leca \& Boxenbaum, 2009). This study explains the institutional change as a complex process where different actors and forces interact constantly in order to balance the regulatory task and the promotion and incentive initiatives that every institution must develop for its own industry or field of organization.

In fact, institutions have to be the solid platform to support the firm's business activity. A platform to enable and facilitate the infrastructure, the commitments of contracts and to secure and protect property rights (Hillmann \& Aven, 2011). Therefore, institutions may be greater importance to underdeveloped societies than to first world ones, because emergent economies need more attention and care from adequate public institutions, in order to obtain good conditions for growth and to attain wealth. For any firm, the presence and good deployment of institutions that perform their purpose are critical in order to follow 
their own strategy. But to obtain relevant institutions that can play an important role in their contexts or industries, they have to mobilize special and strategic resources that are available only if conditions like networks are at the disposal for all the partners involved.

\subsubsection{Firms Strategy and Networks}

In another research we can observe that the actors that interrelate in the same context aren't necessarily equal. There are organized actors and another group of disorganized actors that can possibly contribute significantly to the way every organization models its own strategy (Ansari \& Phillips, 2011). This unorganized group of actors can be for example consumers of a particular good or product. Sometimes consumers have certain power in the industry to change some of the rules or modify the behavior of organizations. Perhaps that kind of power that unorganized groups obtain isn't present everywhere, but however in particular contexts, consumers collectively can achieve more against the manufacturers than when they work individually. The roots of collective and individual ideas may be found in the fact that every structural difference is worthy of attention, not only because the bond or the relation between the actors is important, but also because the actors themselves also may play a significant role in the network theory (Parkhe, Wasserman, \& Ralston, 2006). Every single actor can create a different relation with another, because the particular characteristics which are combined with others can possibly generate a new structure or network in a new organizational field. According to Dyer \& Singh (1998) a firm is capable of building relationships with other firms, so it can find new spaces where there are many sources of competitive advantages that come with the network management and the influence of its leaders in the network.

As consumers sometimes have the power to change the behavior of organizations, there are some particular industries, like telecommunications or video games, where consumer networks can put on the top of sales a product that is not always the best of the category, but is the first in the market who obtain a network of consumers (Shankar \& Bayus, 2003). This consumer network can be an important strategic asset to gain a competitive advantage. Shankar \& Bayus (2003), in an empirical study of home video game industry (the case of Nintendo and Sega), states that despite the size of a network, the strength of the network could be more important defining the strength of the network as the marginal effect of a single unit increase in the demand or sales.

Moreover, some firms that want to integrate their vision to their chain's value have used the network theory to help them generate a new concept of Global Production Network, that implies more than a simple linear relation, but a multi directional network of relationships between actors and participants in a particular industry or organizational field (Levy, 2008). These organizational fields need to obtain valuable resources and mobilize them to mainly improve situations in their particular industries. In order to do so, network management could be extremely necessary, because it can provide firms with those resources and the appropriate relationships to secure its right mobilization in the precise moments. Summarizing network management is perceived as very important to a firm or organization that wants to consolidate a sustainable strategy, not just for the access to valuable resources that it implies, but also for the admittance to multiple relationships 
and partners involved in the firm's production of value. In fact, firms that work in the same supply chain can build networks in order to improve coordination and governance in their relationships (Vurro, Russo \& Perrini, 2009). According to Vurro, Russo \& Perrini (2009) a firm can obtain several benefits from a central position in its network and from the amount of relationships with the other actors in the same supply chain.

A very good measure of the execution of the strategy can be business performance, and business performance is influenced by network resources and entrepreneurial orientation (Yao \& others, 2009). Networks can provide strategic resources to sustain and develop competitive advantages and on the other hand, entrepreneurial orientation provides the search for new opportunities and execution abilities.

\section{Conclusions}

There appears to be a particular intersection between the concepts of strategy and networks. Strategy is built on the competitive advantages of a firm, and in order to achieve and sustain over time these competitive advantages, companies have to obtain different valuable resources like information, reputation, knowledge, learnings capabilities and trust, from their own networks; and constantly search for better opportunities in their organizational fields. Therefore, networks could be responsible for providing the tools and resources for helping to improve the whole and complex concept of strategy. This set of resources is known as the firm's social capital.

In this review we found that there are many ways a company could use their networks to obtain valuable and strategic resources for their businesses. The networks used most frequently were the corporate networks to enable the firm's external resources; and the open or less open network systems in order to achieve more information from the first one and trust and reference from the second, also known as weak and strong ties respectively (Granovetter, 1973). A firm can attempt to draw its network in order to recognize what type of ties are most present in it and what structural holes (Burt, 1992) are present too and could be better to maintain as a structural hole as well.

Organizations or firms are constantly involved in evolution processes. Therefore when companies decide to begin a new venture abroad or begin a corporate entrepreneurship, they have to choose and maintain a sustainable network of relationships inside and outside the firm. Companies are also very influenced by the context of the industry and by the institutions that are working in it. So in particular scenarios, like under developed countries or emergent economies, the use of networks are more important and critical than in other situations.

As networks are dynamic, they are constantly changing the environment where an organization has to work. This implies that the firm has to be aware of any of these changes, in order to secure the accomplishment of its objectives and its strategy as well. The context where a firm took a decision will never be the same again. The firm has to recognize the environment again and identify the available resources from internal and external sources and finally decide how to use them by taking care of the proper time and the correct set of resources for a particular situation. 
From the entrepreneurial point of view, networks are a very reliable source to reduce the uncertainty of new partners and relationships. Moreover, their initiatives may use networks to obtain an exchange of strategic resources with internal and external partners in the organizational field. We have to consider entrepreneurs as new business executives. Their necessity to have access to information and moreover, non-redundant information, is critical to their still small businesses.

In developing countries, network management has special importance because of few opportunities and resources inside the firm or in the environment. In this scenario, networks help as different dynamic source of chances for these organizations. With this knowledge, governments have to promote and develop new spaces for co-working and facilitating generation of events and meetings where firms can connect with each other. This can be an interesting option in some poor countries that could enhance the external resources of networks.

Finally, this review also opens new paths for network and strategy research, in order to establish more links between them that could help academic researchers to understand companies' behavior in different situations, industries and contexts, having the moderate presence of networks and the resources available from their management as well. 


\section{bibliography}

Adler, Paul S. \& Seok-Woo Kwon

2002

«Social capital: Prospects for a new

concept». Academy of Management

Review, 27 (1), pp. 17-40

\section{Ansari, Shahzad \& Nelson}

\section{Phillips}

2011 «Text me! New consumer practices

and change in organizational fields».

Organization Science, 22 (6), pp. 1579-

1599. Retrieved from: <https://doi.

org/10.1287/orsc. $1100.0595>$.

\section{Barney, Jay}

1991

«Firm resources and sustained competitive advantage». Journal of Management

Review, 27 (1), pp. 17-40. Retrieved from:

$<$ https://doi.org/10.1177/01492063910170 $\underline{0108}>$.

\section{Battilana, Julie, Bernard Leca \& Eva Boxenbaum}

«2 how actors change institutions: Towards a theory of institutional entrepreneurship». The Academy of Management Annals, 3

(1), pp. 65-107. Retrieved from: <https://doi. org/10.1080/19416520903053598>

\section{Burt, Ronald}

Structural Holes: The Social Structure of Competition. Harvard University Press.

\section{Burt, Ronald}

"Structural holes and good ideas».

American Journal of Sociology, 110 (2),

pp. 349-399. Retrieved from: <https://doi. org/10.1086/421787>

\section{Coviello, Nicolle}

2006

«The network dynamics of international new ventures». Journal of International Business Studies, 37 (5), pp. 713-731.

Retrieved from: <https://doi.org/10.1057/ palgrave.jibs.8400219>

\section{Dyer, Jeffrey \& Harbir Singh}

1998

«The relational view: Cooperative strategy

and sources of interorganizational

competitive advantage». The Academy

of Management Review, 23 (4), pp.

660-679. Retrieved from: <https://doi.

org/10.2307/259056>

\section{Ellis, Paul D.}

2011

«Social ties and international

entrepreneurship: Opportunities

and constraints affecting firm

internationalization». Journal of

International Business Studies, 42 (1),

pp. 99-127. Retrieved from: <http://doi.

org/10.1057/jibs.2010.20>.

\section{Granovetter, Mark}

1973

"The Strenght of Weak Ties». American Journal of Sociology, 78 (6), pp. 1360

1380. Retrieved from: <https://doi. org/10.1086/225469>

\section{Hillmann, Henning \& Brandy Aven}

«Fragmented networks and entrepreneurship in late imperial Russia». American Journal of Sociology, 117 (2), pp. 484-538. Retrieved from: <http://doi. org/10.1086/661772> 


\section{bibliography}

Hitt, Michael, Duane Ireland, Michael Camp \& Donald Sexton

«Strategic entrepreneurship:

entrepreneurial strategies for wealth

creation». Strategic Management Journal,

22 (6-7), pp. 479-491. Retrieved from:

$<$ http://doi.org/10.1002/smj.196>.

\section{Hung, Shih-Chang}

«Mobilising networks to achieve strategic difference». Long Range Planning, 35 (6), pp. 591-613. Retrieved from: <http://doi. org/10.1016/S0024-6301(02)00150-4>

\section{Kwon, Seok-Woo \& Paul Adler}

«Social capital: Maturation of a field of research". Academy of Management Review, 39 (4), pp. 412-422. Retrieved from: <http://doi.org/10.5465/ amr.2014.0210>

\section{Levy, David L.}

«Political contestation in global

production networks". The Academy of Management Review, 33 (4), pp. 943-963.

Retrieved from: <https://doi.org/10.5465/ amr.2008.34422006>

\section{Maas, Jeroen, Anastasia}

\section{Seferiadis, Joske Bunders \&} Marjolein Zweekhorst

«Bridging the disconnect: How network creation facilitates female Bangladeshi entrepreneurship». International Entrepreneurship and Management Journal, 10 (3), pp. 457-470. Retrieved from: < http:// doi.org/10.1007/s11365-014-0299-2>
Martin, Geoffrey, Remzi Gözübüyük \& Manuel Becerra

"Interlocks and firm perfomance: The role of uncertainty in the directorate interlockperformance relationship». Strategic Management Journal, 36, pp. 235-253.

Retrieved from: <https://doi.org/10.1002/ $\underline{\text { smj.2216> }}$

\section{Mintzberg, Henry}

"Patterns in strategy formation».

Management Science, 24 (9), pp. 934-948.

Retrieved from: <https://doi.org/10.1287/ mnsc.24.9.934>

\section{Mitchell, J. Clyde}

«Social networks». Annual Review of Anthropology, 3, pp. 279-299. Retrieved from: <https://doi.org/10.1146/annurev. an.03.100174.001431>.

\section{Parkhe, Arvind, Stanley Wasserman \& David Ralston} "New frontiers in network theory development». The Academy of Management Journal, 31 (3), pp. 560-568. Retrieved from: <http://www.rcmewhu. com/upload/file/20150528/2015052810342 4 5645.pdf $>$

\section{Peng, Mike, Sunny Li Sun, Brian Pinkham \& Hao Chen}

"The Institution-Based View as a Third Leg for a Strategy Tripod". Academy of Management Perspectives, 23 (3), pp. 6381. Retrieved from: < http://doi.org/10.5465/ AMP.2009.43479264>. 